\title{
Mohamed Cherkaoui: Morocco and the Sahara, social bonds and geopolitical issues
}

\section{The Bardwell Press, 2007}

\author{
Juergen G. Backhaus
}

Published online: 21 January 2012

(C) Springer Science+Business Media, LLC 2012

"To erase history is to mortgage the future." This is the motto of a thoughtful book about Morocco and the Sahara. Basically, the book argues that Morocco's policy of developing the Sahara was successful and hence continuing on the present path beats independence for the Sahara.

His remarkable analysis of some 30,000 marriage contracts shows that contrary to received wisdom, the Saharawis are not a self contained isolated people all by themselves.

After 1975 when the borders fell between the kingdom of Morocco and the (formerly Spanish) Sahara endogamy rates among the studied cases fell by $45 \%$ for men and $39 \%$ for women. What stronger evidence for integration can there be than the bond of marriage?

J. G. Backhaus ( $\square)$

Krupp Chair in Public Finance and Fiscal Sociology, University of Erfurt, Nordhäuser Strasse 63, 99089 Erfurt, Germany

e-mail: juergen.backhaus@uni-erfurt.de 